\title{
THE INFLUENCE OF ASPECT ON PASTURE ENVIRONMENT
}

\author{
M. G. LAMBERT \\ Grasslands Division, DSIR, Palmerston North
}

\section{Abstract}

Large differences in climatic, edaphic, and biotic variables were recorded among four aspects of a hill in the Southern Ruahine range over a twelve-month period. Productivity of the existing sward appeared to be strongly influenced by available soil nitrogen levels, and soil moisture status during the summer/autumn months. Pasture botanical composition was related to both these factors and also to soil available phosphate status. Some practical implications of the differences recorded are discussed with reference to farm subdivision, seeds mixtures and feriiiizer requirements.

\section{INTRODUCTION}

The pasture environMENT comprises soil, climate, animal, and plant components which interact to give a particular state of productivity and stability. In hill country the additional effects of topography result in a unique pasture environment. Topography has its influence through the effects of slope and aspect, both on a micro- and a macro-scale. In this paper attention is focused on aspect effects.

The major direct effects of aspect are climatic ones, namely, on radiation and wind speed. Direct effects on rainfall may also occur (Aldridge, 1975). Indirect effects on other climatic factors, and on the soil, animal and plant components, result from these direct effects on climate.

\section{EXPERIMENTAL AND RESULTS}

Selected environmental variables were studied during 1972 on four aspects of a hill at Ballantrae, the hill country research station of Grasslands Division, DSIR. The experimental area was $370 \mathrm{~m}$ above sea level and the soil type Whetakura hill soil (Rijkse, 1974), a yellow-brown earth derived from sandy siltstone, with a possible loess influence (J. D. Cowie, pers. comm.) . As far as could be determined, the area had not been topdressed since 1950, if at all. Annual rainfall in the years 1970-1975 ranged from 990 to $1350 \mathrm{~mm}$. 
Climate measurements were made on an area of approximately 13" slope on each aspect. Pasture production and nitrogen mineralization measurements were on 5 to $30^{\circ}$ slopes only, and the remaining data were collected on a line transect basis over all slope classes, the average slope being approximately 16 ".

\section{Climatic Factors}

Table 1 summarizes the climatic differences detected between aspects. Rainfall measurements were also made but their relevance is doubtful owing to the probable effects of wind on raingauge catch (Yates, 1970).

TABLE 1: CLIMATIC DIFFERENCES AMONG FOUR ASPECTS AT BALLANTRAE DURING 1972

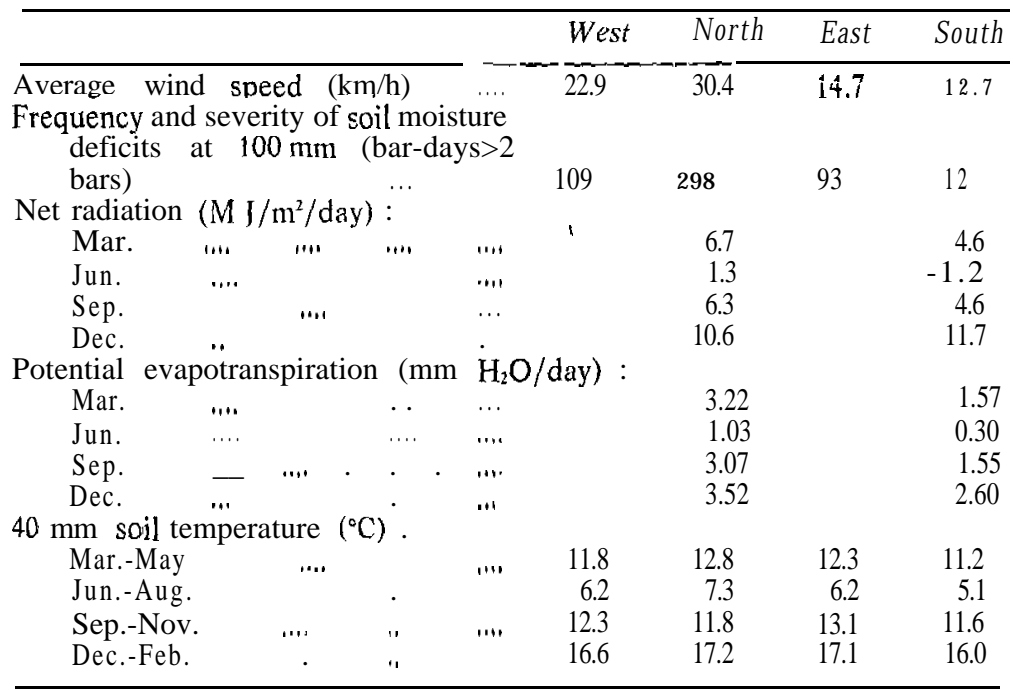

The north aspect experienced much higher wind speeds than the south aspect throughout the year, and higher radiation inputs during autumn, winter, and spring. During summer radiation inputs were slightly higher for the south than for the north aspect, but it is thought that this may have been due in part to the method of calculation used. The north aspect had higher potential evapotranspiration rates than the south aspect during all seasons, and over the November to April period experienced more frequent and severe soil moisture deficits than did the south aspect. The west and east aspects were intermediate to the north 
and south aspects in terms of wind speed and soil moisture status, and would also have been intermediate in terms of radiation (Geiger, 1965).

During the December to August period, the soil temperature of the north aspect was highest and that of the south lowest, the difference being greatest during winter. However, for the remainder of the year, the east aspect was warmest and the temperatures of the north and south aspects similar.

Average air temperatures were similar on all aspects although large differences between aspects did occur on individual days.

\section{ANimal FACTORS}

A cursory examination was made of one of the influences of the grazing animal on the pasture environment, namely, dung return to the sward. The other major animal influences, urine return, grazing and treading, were not monitored. Table 2 lists the relative amounts of dung deposited on each aspect by sheep grazing the area during the period June to December.

TABLE 2: DUNG DEPOSITION BY SHEEP ON FOUR ASPECTS AT BALLANTRAE

(All figures are adjusted to east $=100$ )

\begin{tabular}{|c|c|c|c|c|c|c|}
\hline & & & West & North & East & South \\
\hline Dung deposited & $\cdots$ & & 27.1 & 19.7 & 100.0 & 98.1 \\
\hline $\mathrm{SE}$ & & . & 16.4 & 17.4 & & 26.9 \\
\hline
\end{tabular}

There was a greater amount of dung dropped on the east and south aspects than on the north and west aspects, the amount for the south being disproportionately large when compared with the dry matter production figures of Table 4. Presumably this was due to the tendency of the sheep to camp in the lee of the hill in order to escape the prevailing W-NW wind.

\section{SOIL FACTORS}

Large differences were found to exist in the $0-75 \mathrm{~mm}$ soil nutrient status of the four faces studied. The most noticeable features were the overall high status of the east aspect, high available $\mathrm{P}$ and $\mathrm{K}$ levels of the north aspect, and low $\mathrm{P}$ and $\mathrm{K}$ levels of the south aspect (Table 3). 
TABLE 3: SOIL CHEMICAL AND CLIMATIC CHARACTERISTICS FOR FOUR ASPECTS AT BALLANTRAE

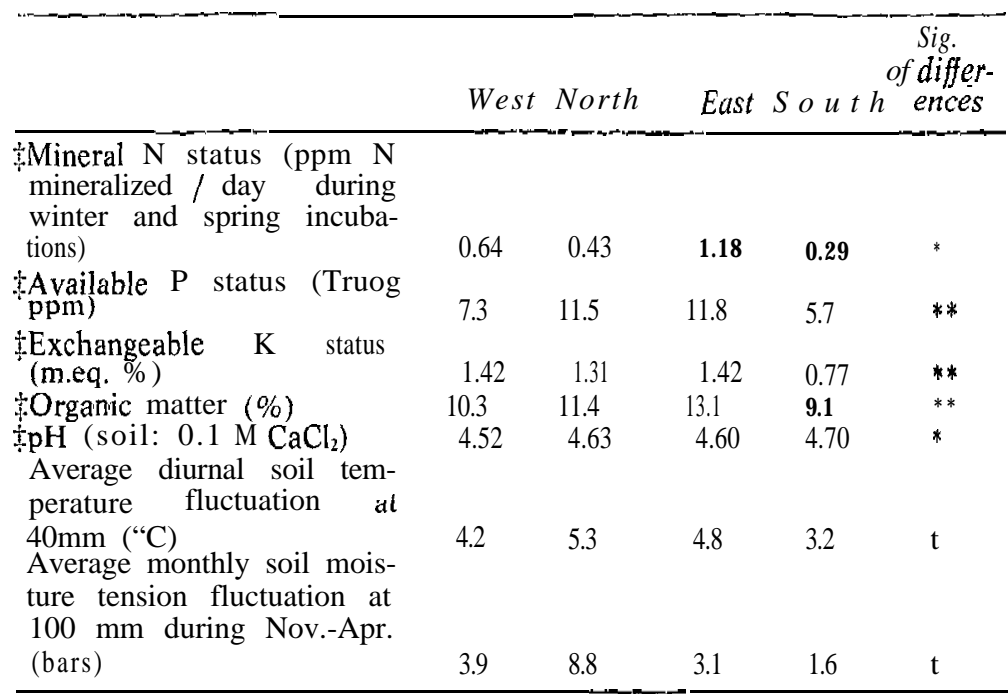

$\$ 0.75 \mathrm{~mm}$ sample depth.

†Significance not tested.

Climate was probably the major influence in the formation of the differences detected. Nutrient transfer between aspects does not appear to have exerted a large influence on soil nutrient status. For example, calculation shows a net input of 3 to $4 \mathrm{~kg} /$ ha/yr of $\mathrm{P}$ to the south aspect and a loss of $1-2 \mathrm{~kg} / \mathrm{ha}$ from the east, north, and west aspects. However, the available $\mathrm{P}$ status of the south aspect was low (Table 3). The west aspect showed signs of having been ploughed and this may account for its overall low nutrient status, through burial of topsoil.

The data presented concur with Ross (1971) and, partially, with Radcliffe (1968). However, the data presented here for north and south faces are the converse of those given by Suckling (1975).

\section{Plant FaCtors}

Extremely large differences existed among aspects in terms of dry matter producion, and botanical composition measured by point analysis (Tabie 4). The main differences in dry matter production were the higher production on the south, compared with the north and west aspects. over the summer/autumn period, and the overall high production on the east aspect (Fig. 1) . The 
chief factor determining production by the existing sward appeared to be $\mathrm{N}$ availability, soil moisture status also becoming important over the drier months of the year. One of the greatest limitations to pasture improvement would be the low available $\mathrm{P}$ status of the soil.

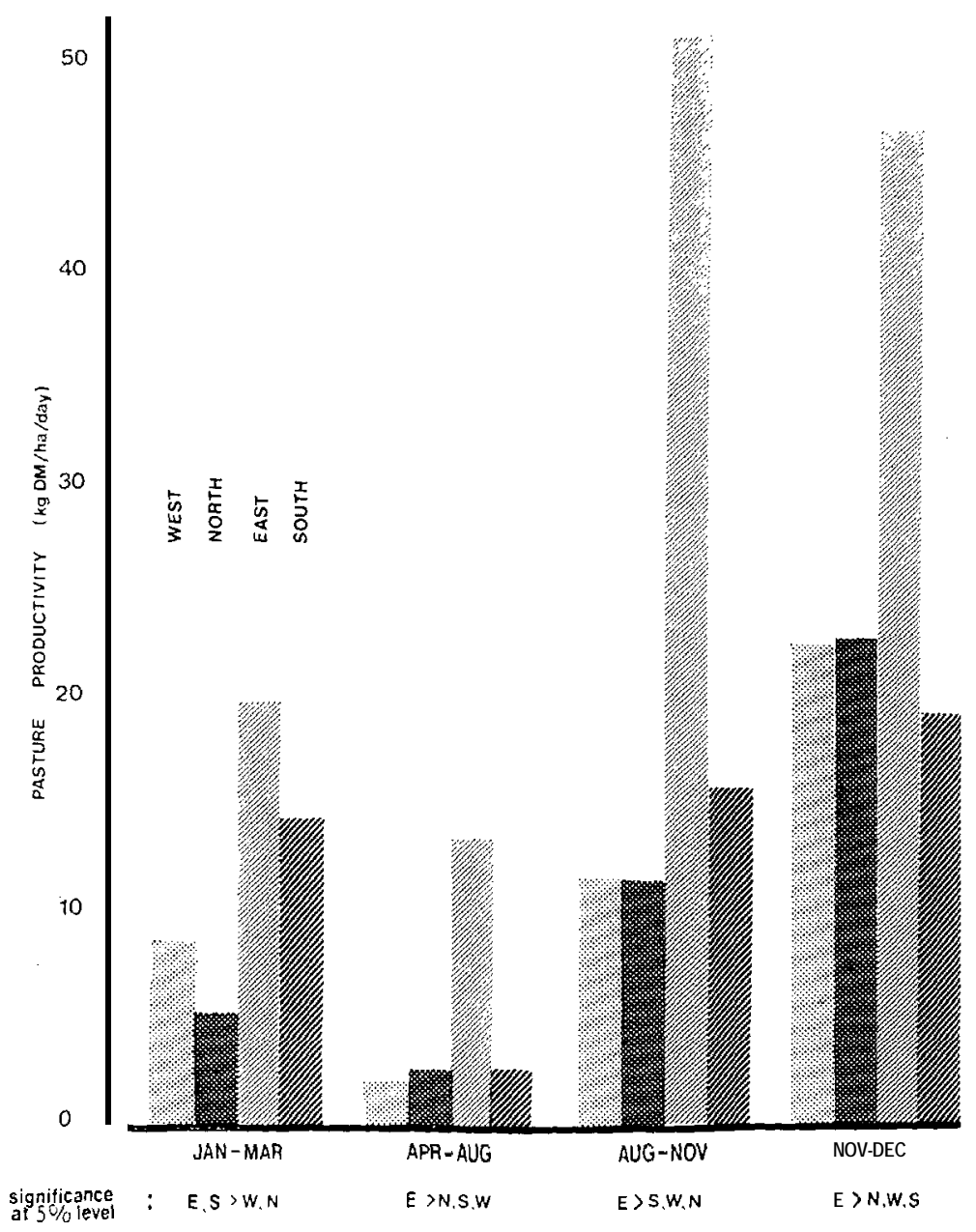

FIG. 1: Pasture productivity on four aspects a! Ballantrae during 1972. 
Botanical composition appeared to be influenced by available soil nitrogen and phosphate status, and also by soil moisture status over the summer and autumn. All aspects were similar in terms of content of "low-fertility tolerant" grass species i.e., browntop (Agrostis tenuis), sweet vernal (A nthoxanthum odoratum), crested dogstail (Cynosurus cristatus), and Chewings fescue (Festuca rubra var. commutata) (Table 4).

TABLE 4: BOTANICAL COMPOSITION AS MEASURED BY POINT ANALYSIS $(\%)$ AND PASTURE PRODUCTION (kg DM/ha/yr) ON FOUR ASPECTS AT BALLANTRAE

\begin{tabular}{|c|c|c|c|c|c|}
\hline & West & North & East & South & $\begin{array}{c}\text { Sig. of } \\
\text { differences }\end{array}$ \\
\hline Annual pasture production & 3095 & $287 \overline{2}$ & 9998 & 3687 & $\%$ \\
\hline $\begin{array}{l}\text { Dantherituspps. } \\
\text { Other "low-fertility tolerant" }\end{array}$ & 3.2 & $12 \pi$ & 4.1 & 1.2 & $*$ \\
\hline $\begin{array}{l}\text { grasses } \\
\text { "High-fertility responsive" }\end{array}$ & 47.4 & 44.8 & 43.5 & 46.9 & $\mathrm{~ns}$ \\
\hline grasses & 5.9 & 3.9 & 22.7 & 9.2 & ** \\
\hline Flatweeds & 22.7 & 20.2 & 16.7 & 19.6 & * \\
\hline Moss & 11.2 & 6.2 & 4.4 & 11.8 & $*$ \\
\hline White clover & 5.7 & 3.4 & 3.9 & 3.9 & $*$ \\
\hline Suckling clover & 5.1 & 0.8 & 0.6 & 1.5 & $* *$ \\
\hline
\end{tabular}

However, flatweeds (Plantago lanceolata, Hypochaeris radicata, Crepis capillaris, and Leontodon taraxacoides) and suckling clover (Trifolium dubium) were most abundant on the low fertility, relatively dry west face, danthonia (Notodanthonia spp.) on the drought-prone north face, and moss on the low $\mathrm{P}$ status south and west faces. The "high-fertility response" grasses i.e., ryegrass (Lolium pererznr), cocksfoot (Dactvlis gfomerata), and Yorkshire fog (Holcus lanatus) - were most abundant on the more fertile east face and the damper south face. Although little white clover (Trifolitum repens) was present in the sward it was most abundant on the west and least abundant on the north aspect.

\section{DISCUSSION}

The data presented illustrate the large differences in pasture environment which can exist among aspects in hill country. Differences of the same or greater magnitude can occur on a microtopographical scale within a hillside owing to the terraced nature of much hill country (Rumball, 1966; Radcliffe, 1968). 


\section{( 1) Farm Subdivision}

Hill country fences are traditionally erected along ridges. A further necessary sophistication is fencing to aspect. Lobb (1940) remarked upon a farmer fencing off shady faces in order to control feed better, and Suckling (1954, 1959, 1966, 1975) has often preached this gospel as a result of his experiences at Te Awa.

Faces of different aspect require differential grazing management for a number of reasons:

(a) To allow exploitation of different seasonal growth patterns. Southerly or shady faces grow more pasture than northerly or sunny faces during the summer and autumn (Fig. 1) and less during the winter and spring (Suckling, 1959).

(b) Legume persistence on exposed faces is a problem in much of New Zealand's drier hill country, especially where attempts are made to introduce improved legume varieties and/or increase the legume content of the sward. Presumably this lack of persistence is due to the frequent drought conditions occurring on these areas (Table 1). Reduction in stock numbers on sunny faces over the dry part of the year may improve legume persistence.

(c) To reduce fertility transfer. The grazing animal tends to graze and excrete differentially according to aspect. Suckling (1954) notes difficulty in forcing animals to graze rank shady faces where subdivision is not according to aspect, as does Hercus (1961), and the data of Table 2 illustrate the biased excretal pattern which can exist among aspects in hill country.

(d) Scrub weed control may be more of a problem on moist shady faces, especially in the hill country to the west of the North Island. These faces may require strategic grazing management in order to suppress weed invasion.

\section{(2) Pasture Seeds Mixtures}

Environmental variation with aspect (Tables 1 and 3) and also with microtopography (Rumball, 1966; Radcliffe, 1968) indicates the potential for more complex seeds mixtures on hill country than on flat land. This concept was advanced by Levy and Cockayne in the 1930s and still has merit since it is obviously more difficult for a simple, as opposed to a more diverse, seed 
mixture to establish and form a productive sward over the range of habitats existing in hill country.

\section{(3) Fertilizer Requirements}

Radcliffe (1968), Saunders and Auld (1969) and the data of Table 3 indicate lower available $\mathrm{P}$ and $\mathrm{K}$ levels on southerly than on northerly faces. Results from Ballantrae (D. A. Grant, unpubl.) indicate the same trend, although the effect is far less pronounced than in the above data. Suckling (1975) presents results for Te Awa which show the converse situation.

Although the limited data available are at times contradictory, the differences recorded in specific instances indicate that differential topdressing of aspects may be a desirable proposition. In many cases this would be possible in practice, especially if carried out in conjunction with avoidance of topdressing of ridge-top stock camps, as suggested by Saunders and Auld (1969) and Gillingham and During (1973). Feasibility would depend on scale of country and aeroplane size. The decision to topdress differentially and actual policy should only be made in conjunction with soil test figures or, preferably, field trial results.

\section{CONCLUSIONS}

Evidence as to the precise differences existing among aspects is at times contradictory, and the differences probably vary with geographical location, fertilizer input, and grazing management. It is evident, however, that large differences in climate. soils, pasture, and animal behaviour do exist and that judicious decisions can turn these differences to advantage in some instances and reduce the adverse effects in others.

\section{KEFERENCES}

Aldridge, R., 1975. The resultant direction and inclination of rainfall at Taita experimental station, New Zealand. J. Hydrol. (N.Z.), 14 (1): 42-54.

Geiger, R., 1965. The Climate Near the G round. Harvard Univ. Press.

Gillingham, A. G.; During, C., 1973. Pasture production and transfer of fertility within a long-established hill pasture. N.Z. Il exp. Agric., 1: 227-32.

Hercus, J. M., 1961. What do sheep eat on tussock grassland? N.Z. II Agric., 103: 73-7.

Lobb, W. R., 1940. Control of hill grazing. N.Z. /l Agric., 61: 123.

Radcliffe., I. E.. 1968. Soil conditions on tracked hillside nastures. N.Z. ll agric. Res., 11: 359-70.

Rijkse, W. C., 1974, Soil map of Woodville County. Jn Land Inventory Survey Woodville County. Dept of Lands and Survey. 
Ross, C. W., 1971. A Study of the Influence of A spect on some Soil Properties of a Kaikoura Steepland Soil under a Tussock Grassland. Unpublished dissertation, Lincoln College.

Rumball, P. J., 1966. A Study of Pasture Pattern in Relation fo Microtopography. Unpublished M.Agr.Sc. thesis, Massey University.

Saunders, W. M. H.; Auld, M. W., 1969. Topdressing within a hill country farm. Proc. Ruakura Fmrs' Conf.: 16-25.

Suckling, F. E. T., 1954. Pasture management trials on unploughable hill country at Te Awa. I. Establishment of experimental area and results for 1949-51. N.Z. /l Sci. Technol., 36A: 237-73.

- 1959. Pasture management trials on unploughable hill country at Te Awa. II. Results for 1951-57. N.Z. Jl agric. Res., 2: 488-543. 1966. Hill Pasture Improvement. A Guide to Better Use of the Hills. Newton King Group and DSIR.

1975. Pasture management trials on unploughable hill country at Te Awa. III. Results for 1959-69. N.Z. Il exp. Agric., 3: 351-436.

Yates, M. E., 1970. Annual Hydrological Research Report No. I for Makara. MOW - Water and Soil Div. 